\title{
Effects of Saharan dust on the microbial community during a large in situ mesocosm experiment in the NW Mediterranean Sea
}

\author{
M. Laghdass ${ }^{1,2}$, S. Blain ${ }^{1,2}$, M. Besseling ${ }^{1,2}$, P. Catala ${ }^{1,2}$, C. Guieu ${ }^{3,4}$, \\ I. Obernosterer ${ }^{1,2, *}$ \\ ${ }^{1}$ UPMC Univ Paris 06, UMR 7621, LOMIC, Observatoire Océanologique, 66651 Banyuls/Mer, France \\ ${ }^{2}$ CNRS, UMR 7621, LOMIC, Observatoire Océanologique, 66651, Banyuls/Mer, France \\ ${ }^{3}$ UPMC Univ Paris 06, UMR 7093, LOV, Observatoire Océanologique, 06230 Villefranche/Mer, France \\ ${ }^{4}$ CNRS, UMR 7093, LOV, Observatoire Océanologique, 06230 Villefranche/Mer, France
}

\begin{abstract}
The response of the microbial community to Saharan dust deposition was investigated in 6 large mesocosms $\left(52 \mathrm{~m}^{3}\right)$ deployed at an oligotrophic coastal site in the NW Mediterranean Sea in June 2008 (DUNE project). The mesocosms represented well the environmental conditions observed at the study site during the $8 \mathrm{~d}$ experimental period, and the triplicate mesocosms exhibited high reproducibility for each treatment. Dust deposition resulted in an increase in chlorophyll a concentration $\left(0.22 \pm 0.03 \mu \mathrm{g} \mathrm{l}^{-1}\right)$, as compared to that in the control treatments $\left(0.12 \pm 0.01 \mu \mathrm{g} \mathrm{l}^{-1}\right)$, but no treatment effect was observed for bacterial heterotrophic abundance at $5 \mathrm{~m}$ depth. Results from the fingerprinting technique CE-SSCP indicate a temporal evolution of the structure of the total (16S rRNA gene) and active (16S rRNA transcripts) bacterial community, and Saharan dust deposition had a noticeable structuring effect on the active bacterial community. Combining results from 16S rRNA gene clone libraries and CE-SSCP indicates that the relative contribution of Alteromonas macleodii to the active bacterial community was enhanced 2-fold following dust addition. The 2 operational taxonomic units (OTUs) Thiothrix and Alteromonas, belonging to Gammaproteobacteria, and the Bacteroidetes OTU NS5-1 were specific to the clone libraries from the dust-amended mesocosms or more abundant in these than in the control ones. CARD-FISH analyses, however, indicate that these OTUs had overall low abundances (1 to $5 \%$ of total DAPI-counts). Despite the pronounced temporal trend observed during the experimental period, dust deposition had a small, but noticeable structuring effect on the heterotrophic bacterial community that was detectable only at the OTU level at $99 \%$ similarity of the 16S rRNA gene.
\end{abstract}

KEY WORDS: Saharan dust deposition · In situ mesocosms · CE-SSCP · CARD-FISH · Clone libraries · Alteromonas macleodii $\cdot$ NW Mediterranean Sea

\section{INTRODUCTION}

Dry and wet atmospheric deposition represents a significant source of inorganic and organic nutrients and organic carbon to the ocean (Jickells et al. 2005, Jurado et al. 2008). In high-nutrient low-chlorophyll regions, dust deposition enhances iron availability and thus stimulates phytoplankton primary production and potentially carbon dioxide drawdown (Boyd et al. 2007, Cassar et al. 2007). In low-nutrient low-chlorophyll (LNLC) regions, the simultaneous input of phosphate and iron from dust could create a favourable environment for enhanced dinitrogen fixation (Mills et al. 2004). In the subtropical northeast Atlantic Ocean, 
dust addition markedly stimulated phytoplankton primary production and induced a shift from Cyanobacteria to diatoms, while the response in microbial community respiration was minor, resulting in an increase in the ratio of primary production to respiration (Duarte et al. 2006). In contrast, estuarine heterotrophic bacterial and phytoplankton primary production were both stimulated by organic nitrogen introduced by rainfall (Seitzinger \& Sanders 1999). These studies demonstrate that atmospheric inputs can impact autotrophic and heterotrophic microbial communities with important consequences for ocean biogeochemistry.

In the Mediterranean Sea, which is during the stratified period mostly a LNLC region, Saharan dust events represent a dominant source of atmospheric deposition. Previous studies have demonstrated that, during the summer stratification period, atmospheric dust is the main external source of phosphorus (Ridame \& Guieu 2002) and of iron (Bonnet \& Guieu 2006) in the surface mixed layer. Microcosm experiments performed in coastal and offshore Mediterranean waters have shown that dust stimulated primary production (Bonnet et al. 2005, Herut et al. 2005, Lekunberri et al. 2010) and is suspected to stimulate nitrogen fixation (Bonnet \& Guieu 2006). Direct observations of natural dust deposition events in the eastern (Herut et al. 2005) and western (Pulido-Villena et al. 2008) Mediterranean Sea and in a Mediterranean reservoir (Reche et al. 2009) revealed increases in the abundance and metabolism of autotrophic and heterotrophic microbial populations.

While the observed response of the phytoplankton community was linked in some studies to changes in major functional groups (Herut et al. 2005, Duarte et al. 2006), little is known about the effect of dust addition on the structure of the heterotrophic bacterial community. Using microcosm experiments with water from a Mediterranean reservoir, Reche et al. (2009) observed no noticeable differences in the bacterial diversity and richness between dust-amended and control treatments. Conversely, dust addition induced changes in the bacterial community composition in microcosms performed with coastal Mediterranean waters (Lekunberri et al. 2010). The only study that has thus far investigated the impact of dust on the activity of specific bacterial groups reports that instantaneous metabolic rates of Prochlorococcus and a bacterial subpopulation dominated by SAR11 were reduced upon dust addition in the North Atlantic Ocean (Hill et al. 2010). This study suggests that the community response was linked to changes in the microbial community structure (Hill et al. 2010). The question of whether the response of specific bacterial groups to dust addition could play an important role in the cycling of elements introduced by dust, however, remains poorly understood.
The objective of the present study was to investigate the impact of dust deposition on the structure of the total and active bacterial community and to identify the bacterial groups that were most responsive to dust addition. We used, for the first time in this context, large trace-metal-clean in situ mesocosms that allowed us to test for dust deposition effects close to in situ conditions in LNLC waters.

\section{MATERIALS AND METHODS}

Study site and sample collection. The results presented here were obtained during the first field campaign of the DUNE project (A DUst experiment in a low Nutrient, low chlorophyll Ecosystem, www. obs-vlfr.fr/LOV/DUNE). A detailed description of the mesocosms, the collection and treatment of the Saharan dust, the dust deposition and the sampling is given by Guieu et al. (2010). Briefly, Saharan dust was collected in Tunisia, a dominant source region of atmospheric dust for the NW Mediterranean Sea. Saharan dust was submitted to mechanical and physicochemical transformations before deposition in the mesocosms. The finest fraction $(<20 \mu \mathrm{m})$ was used for the experiment since dust particles larger than $20 \mu \mathrm{m}$ are rapidly removed during atmospheric transport (Maring et al. 2003). In the present study, the fertilization mimicked a wet deposition event using evapocondensed dust. Six large mesocosms, each containing $52 \mathrm{~m}^{3}$ of raw seawater and extending to $15 \mathrm{~m}$ depth, were deployed at a coastal site in the NW Mediterranean Sea (Bay of Elbo, Corsica, France: $42^{\circ} 22^{\prime} \mathrm{N}, 8^{\circ} 33^{\prime} \mathrm{E}$ ) in June 2008. Of the 6 mesocosms, 3 were amended with each $10 \mathrm{~g} \mathrm{~m}^{-2}$ of Saharan dust simulating a relatively strong atmospheric dust event (hereafter referred to as D-mesocosms), and 3 mesocosms were established as controls (hereafter referred to as C-mesocosms). Samples from the 6 mesocosms were taken at $5 \mathrm{~m}$ depth before dust addition $\left(t_{0}\right)$, and after $3 \mathrm{~d}\left(\mathrm{t}_{3}\right), 6 \mathrm{~d}\left(\mathrm{t}_{6}\right)$ and $8 \mathrm{~d}\left(\mathrm{t}_{8}\right)$ after the amendment. Real-time measurements revealed that several biogeochemical parameters remained stable between $t_{3}$ and $t_{8}$ i therefore, the experiment was terminated after $8 \mathrm{~d}$. Samples were collected from a floating platform, using a Teflon pump. Throughout the experiment, seawater was also collected outside the mesocosms (hereafter referred to as OUT, $\mathrm{n}=1$ ) at a distance of about $50 \mathrm{~m}$. Water temperature was $19.8 \pm 0.5^{\circ} \mathrm{C}$ inside all mesocosms throughout the experiment, as was the water temperature outside the mesocosms.

Enumeration of heterotrophic bacteria, autotrophic prokaryotic and eukaryotic cells. The abundance of heterotrophic bacteria, autotrophic prokaryotic and eukaryotic cells was determined by flow cytometry 
according to previously described protocols (Lebaron et al. 1998, Marie et al. 2000). Subsamples (2 ml for heterotrophic bacteria and $4 \mathrm{ml}$ for autotrophic cells) were fixed with $2 \%$ formaldehyde (final conc.), incubated for $30 \mathrm{~min}$ at $4{ }^{\circ} \mathrm{C}$, frozen in liquid nitrogen and stored at $-80^{\circ} \mathrm{C}$ until analysis. Synechococcus spp. were discriminated by their strong orange fluorescence (>630 nm) and pico- and nanoeukaryotes were discriminated by their scatter signals of the red fluorescence at $585 \pm 21 \mathrm{~nm}$. For heterotrophic bacteria, samples were stained with SYBR Green I (Invitrogen Molecular Probes) at $0.025 \%$ (vol/vol) final concentration for $15 \mathrm{~min}$ at room temperature in the dark. Counts were performed with a FACSCalibur flow cytometer (Becton Dickinson) equipped with an air-cooled argon laser (488 nm, $15 \mathrm{~mW})$. Stained bacterial cells, excited at $488 \mathrm{~nm}$, were discriminated and enumerated according to their right-angle light scatter (SSC, related to cell size) and green fluorescence measured at $530 \pm$ $30 \mathrm{~nm}$.

Concentration of chlorophyll a. To determine the concentration of chlorophyll $a, 21$ of raw seawater were filtered on GFF filters ( $25 \mathrm{~mm}$ diameter). Filters were extracted in acetone, and the concentration of chlorophyll a was determined by fluorometry on a Trilogy Laboratory Fluorometer (Turner Designs).

Nucleic acid extraction. To determine the bacterial community structure by the fingerprinting method CESSCP, raw seawater (0.5-1 l) was first prefiltered through a $3 \mu \mathrm{m}$ pore size filter (47 mm, Nucleopore), and the $<3 \mu \mathrm{m}$ filtrate sequentially filtered through a $0.8 \mu \mathrm{m}$ PC filter (47 mm, Nucleopore), and a $0.2 \mu \mathrm{m}$ PC filter, respectively, using a peristaltic pump. The $0.8 \mu \mathrm{m}$ and $0.2 \mu \mathrm{m}$ PC filtrates were stored frozen at $-80^{\circ} \mathrm{C}$ until DNA and RNA extraction. For both size fractions, the structure of the total (16S rRNA genes) and active (16S rRNA transcripts) bacterial communities was determined, based on the DNA and RNA extracts, respectively.

For DNA and RNA extraction the PC filters were submerged in $425 \mu$ lysis buffer (40 mM EDTA, $50 \mathrm{mM}$ Tris, $0.75 \mathrm{M}$ sucrose) and then subjected to 3 freezethaw cycles using liquid nitrogen and a water bath at $65^{\circ} \mathrm{C}$. Freshly prepared lysozyme solution $\left(1 \mathrm{mg} \mathrm{ml}^{-1}\right)$ was added to the PC filters and incubated at $37^{\circ} \mathrm{C}$ for $45 \mathrm{~min}$. Proteinase $\mathrm{K}\left(0.2 \mathrm{mg} \mathrm{ml}^{-1}\right)$ and sodium dodecyl sulphate (SDS $1 \%$ ) were then added and the PC filters were incubated at $55^{\circ} \mathrm{C}$ for $1 \mathrm{~h}$. Purification of DNA and RNA was performed with the Qiagen AllPrep DNA/RNA extraction kit. $1.5 \mathrm{ml}$ RLT+ buffer (Qiagen) containing $14.3 \mathrm{M} \beta$-mercapthoethanol was added, mixed well and incubated for $10 \mathrm{~min}$ at room temperature. The DNA and RNA were purified separately from the lysate on the individual columns according to the manufacturer's instructions. The molecular size and the purity of the DNA were analysed by agarose gel electrophoresis (1\%).

Reverse transcription of RNA. RNA samples $(2 \mu \mathrm{g})$ were incubated together with $0.5 \mathrm{ml}$ primer w34 (1 mM final concentration) at $94^{\circ} \mathrm{C}$ for 5 min before cooling rapidly in a water/ice bath. Reverse transcription was achieved by adding $5 \mathrm{ml}$ of deoxynucleoside triphosphates (dNTPs; $0.8 \mathrm{mM}$ final concentration), $1 \mathrm{ml}$ of Moloney murine leukemia virus (M-MLV) reverse transcriptase $(20 \mathrm{U})$ and $5 \mu \mathrm{l}$ of $5 \mathrm{X}$ M-MLV buffer (Promega) and allowing the reaction to proceed at $42^{\circ} \mathrm{C}$ for $1 \mathrm{~h}$. The cDNA samples were stored at $-20^{\circ} \mathrm{C}$.

Capillary electrophoresis - single-strand conformation polymorphism analysis (CE-SSCP). CE-SSCP is a fingerprinting method that allows an image to be obtained of the structure of the total (16S rRNA genes) and active (16S rRNA transcripts) bacterial community. CE-SSCP enables determination of the presence and relative abundance of up to 40 of the most abundant operational taxonomic units (OTUs) of varying taxonomic ranks (Lami et al. 2009, West et al. 2008). Short fragments $(\sim 200 \mathrm{bp})$ of the V3 region of the $16 \mathrm{~S}$ rRNA gene were amplified from DNA or from a cDNA copy of the RNA using the bacterial specific primers w49 (5'-ACG GTC CAG ACT CCT ACG GG-3') (Delbes et al. 2000) and w34 (5'-TTA CCG CGG TGC TGG CAC-3') (Lee et al. 1996), the latter 5' labelled with phosphoramidite (TET, Eurogentec). Amplifications were performed according to a previously described protocol (West et al. 2008). The electropherograms were analysed by GeneScan software (Applied Biosystems), using the second-order least square size calling method to normalize mobilities between different runs as described previously (Ghiglione et al. 2005). The similarity of the SSCP profiles was assessed as described previously (West et al. 2008) by using SAFUM software (Zemb et al. 2007), which normalizes the total area of the SSCP profiles and the mobilities between different runs using the internal standard. The BrayCurtis distance was then calculated and similarity dendrograms were constructed using the complete linkage method by using Primer-E5 software package (Clarke \& Warwick 2001).

Assignment of environmental CE-SSCP peaks. The 16S rRNA genes of several clones from each OTU determined from the clone libraries as described below were amplified directly from E. coli cells in PCR reaction mixes according to a previously described protocol (West et al. 2008). The clone electropherograms were superimposed on the environmental profiles for peak assignment. The areas of the peaks that could be assigned from the clones were obtained after peak detection by GeneScan Analysis.

Sequencing and phylogenetic analysis of 16S rRNA gene clone libraries. To investigate the composition of 
the bacterial community, 16S rRNA clone libraries were constructed for the $<0.8 \mu \mathrm{m}$ fraction for one C-mesocosm and one D-mesocosm at $5 \mathrm{~m}$ depth at the end of the experiment. The results from the clone libraries enabled CE-SSCP peak assignment and probe design. The clone libraries were constructed according to the methods described previously (West et al. 2008). Plasmid DNA (192 clones for each library) was sequenced using the BigDye ${ }^{\mathrm{TM}}$ Terminator kit and the 3730xl Automatic Sequencer by Macrogen using primer 27F (5'-AGA GTT TGA TCM TGG CTC AG-3'). The software BioEdit version 7.0.9.0 (Tom Hall, Ibis Therapeutics) was used to visualize the electropherograms and the sequences were trimmed by PHRED (Ewing et al. 1998). All sequences were checked for chimera formation using CHECK_CHIMERA software (Maidak et al. 2001) and Bellerophon (Hugenholtzt \& Huber 2003). A total of 33 clones were eliminated (plastids and bad sequences). Phylogenetic groups or OTUs were defined at $99 \%$ similarity from the exported CLUSTALW alignment using Clusterer software with the single linkage setting (Klepac-Ceraj et al. 2006). The closest relatives were found by submitting a representative sequence of each OTU to BLASTN. Each OTU was named by the closest BLAST hit or by clusters previously identified. One or more sequences from the OTU were fully sequenced as described above using the primer $1492 \mathrm{R}$ (5'-TAC GGY TAC CTT GTT ACG ACT T-3') and the full-length sequences were assembled in BioEdit. The nucleotide sequences data from this study have been deposited in the GenBank database under the accession numbers HM117272 to HM117275 (plastid sequences), HM117276 to HM117458 (C-mesocosm bacterial sequences), HM117459 to HM117462 (cyanobacterial sequences) and HM117263 to HM117626 (D-mesocosm bacterial sequences).

Probe design and specificity. The probes Thiothrix_577a (5'-GCA TCA CAT CCT ACG TAC-3'), Thiothrix_577b (5'-GCA TTA CAT CCT ACG TAC-3') and NS5_175 (5'-TAT CAG GAT CGT ATG GGG-3') were designed and their specificity evaluated using the PROBE Design and PROBE Match tools of the ARB software package and the greengenes.arb database (Ludwig et al. 2004). As a cultured representative of the Thiothrix and NS5-1 OTU was not available, the hybridization conditions were optimized by carrying out hybridizations with the $t_{8}$ samples using different formamide concentrations (from $45 \%$ to $60 \%$ ). To obtain maximum specificity of the probe, the formamide concentration with highest fluorescence signal was selected ( $55 \%$ ).

Abundance of major and specific bacteria using CARD-FISH. We applied CARD-FISH (Pernthaler et al. 2002) to determine the quantitative importance of major phylogenetic and more specific bacterial groups.
CARD-FISH was performed using general and specific rRNA-targeted oligonucleotide probes labelled with horse- radish peroxidase (HRP; ThermoScientific). The probes Eub338-I, -II and -III (Amann et al. 1990, Daims et al. 1999), Alf968 (Amann et al. 1997), Gam42a (Manz et al. 1992) Bet42a and CF319a (Manz et al. 1996) were used to target most of the domain Bacteria and the major bacterial groups. A negative probe (the Eub antisense probe Non338) was used to determine nonspecific binding (Glöckner et al. 1999). Unlabeled competitor probes were used for Betaproteobacteria and Gammaproteobacteria (Manz et al. 1992). The more specific probes used in this study were SAR11-152R, SAR11-441R, SAR11-542R, SAR11-732R (SAR11 cluster) (Morris et al. 2002), Ros537 (Roseobacter-Sulfitobacter-Silicibacter group) (Eilers et al. 2001), SAR86 (SAR86 cluster) (Eilers et al. 2000) and ALT1413 (Alteromonas group) (Eilers et al. 2000). The recently designed probe NorSea72_88 (5'-GCC ACT CGT CAT CAG ATT-3') and 2 helper probes NorSea72_69H (5'CCA AGC AAT CCA TGT TAC-3' and NorSea72 107H (5'-GCG TTA CGC ACC CGT GC-3') (NorSea72 group belonging to Bacteroidetes) (Laghdass et al. 2010) were also applied in the present study. Two probes were specifically designed to target the group Thiothrix belonging to Gammaproteobacteria (Thiothrix_577a and Thiothrix_577b) and a part of the NS5 cluster (NS5-1) within Bacteroidetes (NS5_175) (see Table 2).

For each sample, $100 \mathrm{ml}$ of raw seawater were filtered onto $0.2 \mu \mathrm{m}$ PC membranes $(47 \mathrm{~mm})$ and incubated overnight at $4^{\circ} \mathrm{C}$ on pads soaked with $2 \%$ paraformaldehyde (PFA). Membranes were rinsed with $0.2 \mu \mathrm{m}$ filtered Milli-Q water and dried before storing at $-20^{\circ} \mathrm{C}$ until CARD-FISH analysis as described previously (Pernthaler et al. 2002, Sekar et al. 2003). The total number of cells (DAPI cells) and cells affiliated with a specific bacterial group (FITC labelled) were counted using semi-automated microscopy (Olympus Provis AX70) and an image analysis system (ImagePro). Data were collected from 10 counted fields with at least 300 cells per sample. Relative abundances of the bacterial groups are presented either as mean values and standard errors of cell counts of 10 microscopic fields or as mean values and standard deviations of triplicate filter pieces (see Table 3).

\section{RESULTS}

\section{Response in the abundance and biomass of the microbial community}

The addition of Saharan dust resulted in a rapid increase in phytoplankton biomass at $5 \mathrm{~m}$ depth 
Table 1. Temporal changes in the chl a concentration $\left(\mu \mathrm{g} \mathrm{l}^{-1}\right)$, the abundance of Synechoccocus spp., pico- and nanoeukaryotes and heterotrophic bacteria at $5 \mathrm{~m}$ depth in the control mesocosms $(C, n=3)$, the dust-amended mesocosms $(D, n=3)$, and samples collected outside the mesocosms (OUT, $n=1$ ). Samples were collected before dust-addition $\left(t_{0}\right)$, after $3 \mathrm{~d}\left(\mathrm{t}_{3}\right), 6 \mathrm{~d}\left(\mathrm{t}_{6}\right)$ and $8 \mathrm{~d}\left(\mathrm{t}_{8}\right)$. Mean values $\pm \mathrm{SD}$ of the $3 \mathrm{C}$ - and $3 \mathrm{D}$-mesocosms are given. At $\mathrm{t}_{0}$, the samples of the C-and D-mesocosms, and the OUT sample were pooled $(\mathrm{n}=7)$

\begin{tabular}{|c|c|c|c|c|c|c|c|c|c|c|}
\hline \multirow{2}{*}{ Treatment } & \multirow{2}{*}{$t_{0}$} & \multicolumn{3}{|c|}{$-t_{3}$} & \multicolumn{3}{|c|}{$\mathrm{t}_{6}$} & \multicolumn{3}{|c|}{$\mathrm{t}_{8}$} \\
\hline & & $\mathrm{C}$ & D & OUT & $\mathrm{C}$ & D & OUT & $\mathrm{C}$ & D & OUT \\
\hline Chl a & $0.09 \pm 0.02$ & $0.13 \pm 0.03$ & $0.20 \pm 0.01$ & 0.12 & $0.09 \pm 0.01$ & $0.21 \pm 0.03$ & 0.10 & $0.12 \pm 0.01$ & $10.22 \pm 0.03$ & 0.14 \\
\hline $\begin{array}{l}\text { Synechococcus spp } \\
\left(\times 10^{3} \text { cells ml }{ }^{-1}\right)\end{array}$ & $14.6 \pm 1.3$ & $12.8 \pm 1.9$ & $16.8 \pm 1.2$ & 14.0 & $13.6 \pm 3.9$ & $16.8 \pm 0.7$ & 12.7 & $12.8 \pm 1.1$ & $16.6 \pm 2.6$ & 15.6 \\
\hline $\begin{array}{l}\text { Pico- and nano- } \\
\text { eukaryotes } \\
\left(\text { cells } \mathrm{ml}^{-1}\right)\end{array}$ & $471 \pm 120$ & $706 \pm 192$ & $805 \pm 109$ & 684 & $827 \pm 197$ & $1190 \pm 73$ & 645 & $946 \pm 41$ & $1120 \pm 122$ & 888 \\
\hline $\begin{array}{l}\text { Heterotrophic } \\
\text { bacteria } \\
\left(\times 10^{5} \text { cells ml }{ }^{-1}\right)\end{array}$ & $3.40 \pm 0.3$ & $4.75 \pm 0.5$ & $5.13 \pm 0.3$ & 4.50 & $5.65 \pm 0.2$ & $4.75 \pm 0.3$ & 4.72 & $5.88 \pm 0.3$ & $5.25 \pm 0.3$ & 5.07 \\
\hline
\end{tabular}

(Table 1). The initial concentration of chlorophyll a (chl a) was $0.09 \mathrm{\mu g} \mathrm{l}^{-1}$ and it was about 2 -fold higher in the D-mesocosms than in the C-mesocosms and the OUT samples throughout the experiment. The abundance of Synechococcus spp. was higher in the Dmesocosms $\left(17 \times 10^{3}\right.$ cells $\left.\mathrm{ml}^{-1}\right)$ than in the $\mathrm{C}$-mesocosms and OUT samples (13 to $14 \times 10^{3}$ cells ml-1 $\mathrm{m}^{-1}$, but only at $t_{3}$ and $t_{6}$. Pico- and nanoeukaryotes revealed $a$ different pattern, with higher abundances at $t_{6}$ and $t_{8}$ in the D-mesocosms $\left(1155 \pm 98\right.$ cells ml $^{-1}$, mean $\pm \mathrm{SD}$ of $\mathrm{t}_{6}$ and $\left.t_{8}, n=6\right)$ than in the $C$-mesocosms $(898 \pm 121$ cells $\mathrm{ml}^{-1}$, mean $\pm \mathrm{SD}$ of $\mathrm{t}_{6}$ and $\mathrm{t}_{8}, \mathrm{n}=6$ ) and the OUT samples $\left(766 \pm 171\right.$ cells $\mathrm{ml}^{-1}$, mean $\pm \mathrm{SD}$ of $\mathrm{t}_{6}$ and $\left.\mathrm{t}_{8}, \mathrm{n}=2\right)$ (Table 1). Before dust addition, heterotrophic bacterial abundance was $3.40 \pm 0.3 \times 10^{5}$ cells ml $^{-1}$ (mean $\pm \mathrm{SD}, \mathrm{n}$ $=7$ ) and bacterial abundance varied between 4.5 and $5.88 \times 10^{5}$ cells $\mathrm{ml}^{-1}$ during the $8 \mathrm{~d}$ of the experiment with no pronounced differences detectable at $5 \mathrm{~m}$ depth between the D- and C-mesocosms (Table 1).

\section{Temporal pattern of the bacterial community structure}

The structure of the total and active bacterial community was examined by 16S rRNA gene and the $16 \mathrm{~S}$ rRNA transcript CE-SSCP profiles. The Bray-Curtis dendrograms based on the presence or absence of peaks (corresponding to OTUs) and on the relative peak height are presented in Fig. 1. Overall, the CESSCP profiles of the 3 replicate C-mesocosms and Dmesocosms revealed good reproducibility throughout the experiment. CE-SSCP profiles of the total bacterial community were clustered according to the time point of sampling and the size fraction, but independent of treatment (Fig. 1A). This pronounced temporal trend was observed not only in all mesocosms, but also in the OUT samples. The dendrogram based on the rRNA transcripts, representative for the active bacterial community, revealed a similar temporal pattern (Fig. 1B). However, $8 \mathrm{~d}$ after dust addition, a treatment effect was detectable on the active community of the $>0.8 \mu \mathrm{m}$ size fraction (Fig. 1B).

\section{Composition of the bacterial community}

To identify the most abundant OTUs of the bacterial communities, 16S rRNA gene clone libraries were constructed at $t_{8}$ for $1 \mathrm{C}$ - and $1 \mathrm{D}$-mesocosm. Due to the higher number of OTUs present on the CE-SSCP profiles of the $<0.8 \mu \mathrm{m}$ size fraction $(16 \pm 1$, mean $\pm \mathrm{SD}, \mathrm{n}$ $=6)$ than of the $>0.8 \mu \mathrm{m}$ size fraction $(14 \pm 0.5$, mean \pm $\mathrm{SD}, \mathrm{n}=5$ ), the clone libraries were constructed for the former size fraction. A total of 351 clone sequences for the 2 clone libraries were analyzed. The cyanobacterial sequences accounted for 0.5 and $2 \%$ in the control and dust libraries, respectively, and they were excluded from further analyses. Alphaproteobacteria was the dominant group in both clone libraries (69 and $58 \%$ of total bacterial clone sequences in the C- and Dlibrary, respectively) (Table 2). The contribution of Bacteroidetes was substantially smaller and similar in both clone libraries (about 10\% of the total bacterial clone sequences). By contrast, the relative contribution of Gammaproteobacteria clones was roughly 2-fold higher in the D- than in the C-library (27 and $14 \%$ of total bacterial clone sequences, respectively).

When the sequences were clustered at $99 \%$ similarity of the 16S rRNA gene, a few noticeable differences between the 2 clone libraries were detectable. The cluster analysis resulted in the same number of OTUs 


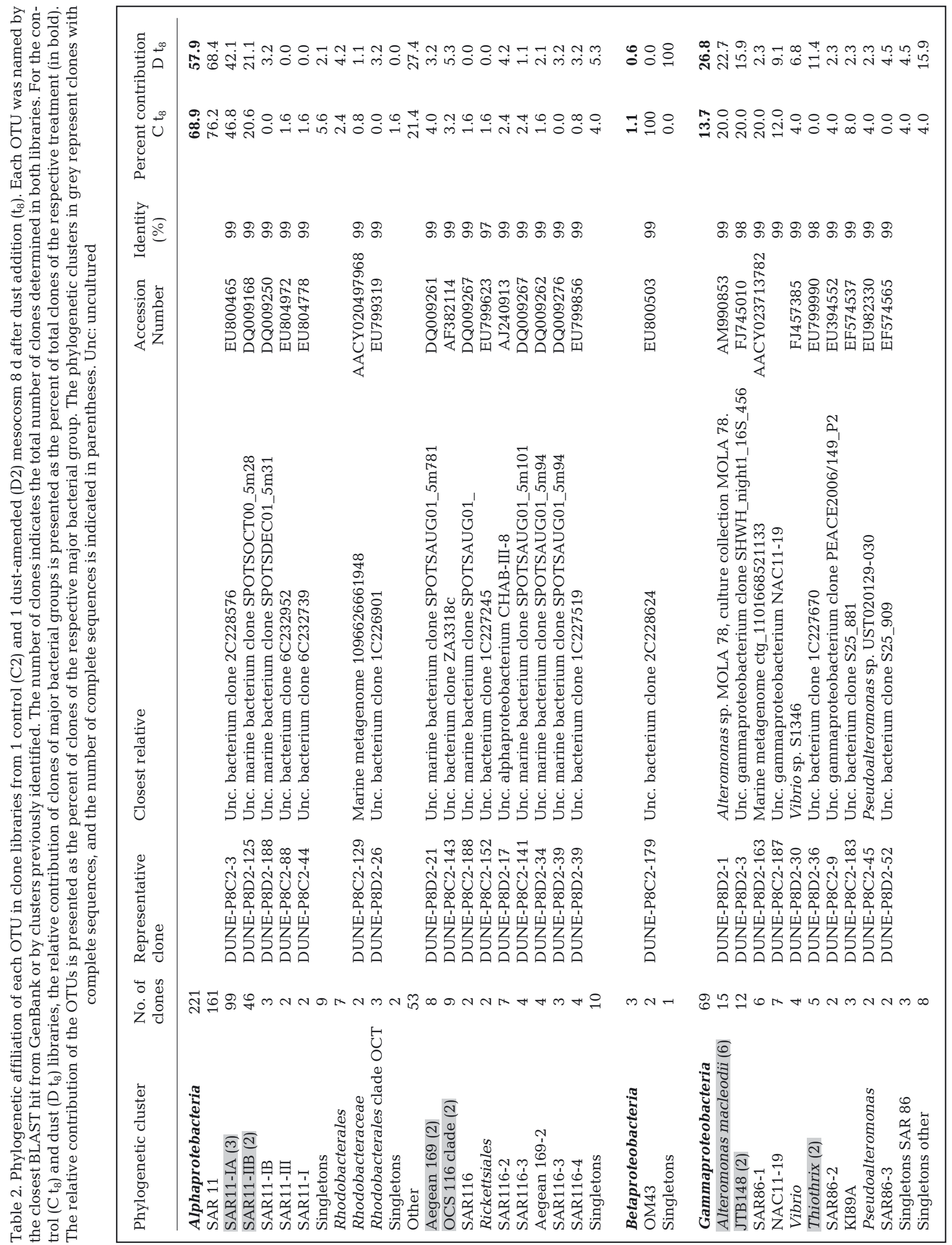




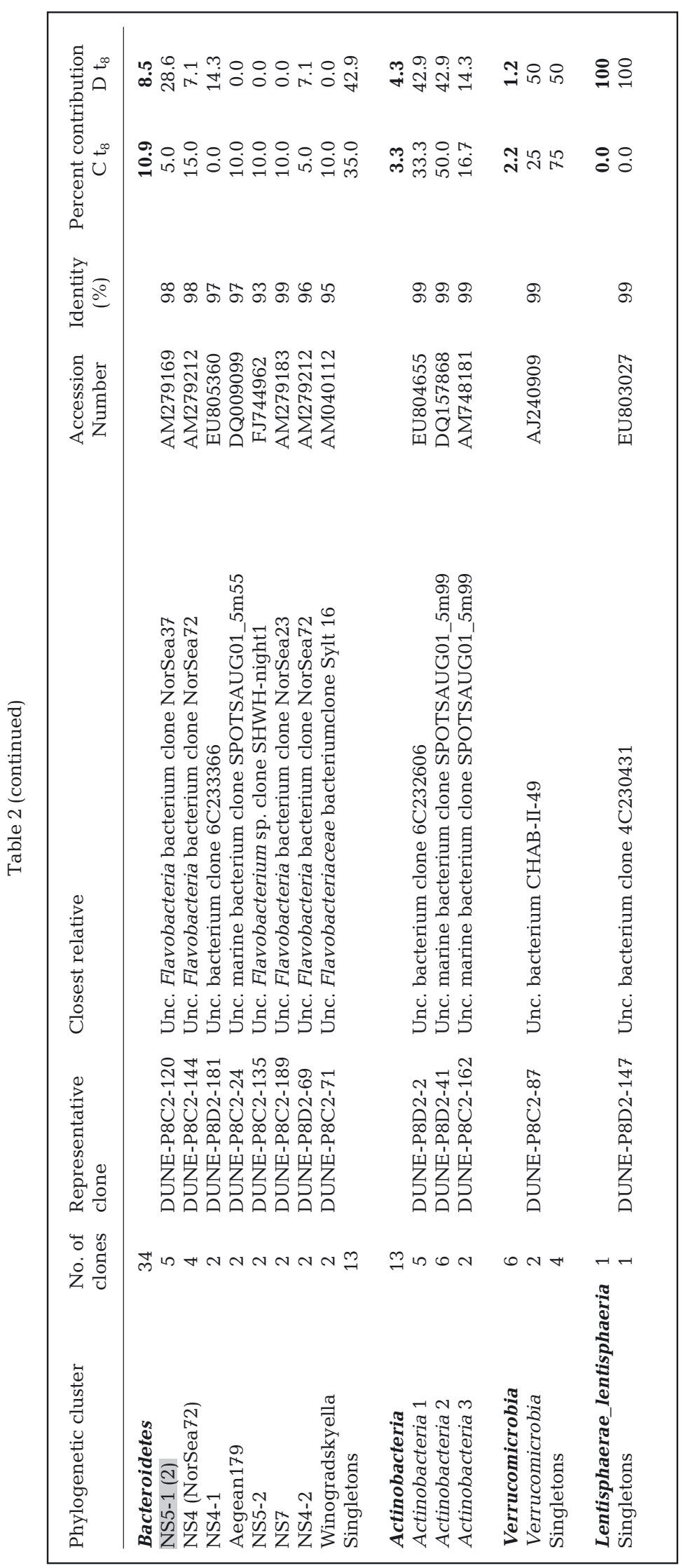

(33) and singletons (26) for both libraries (Table 2). A higher number of OTUs was determined for Alphaproteobacteria (16 OTUs), whereas only 10 and 8 OTUs were determined for Gammaproteobacteria and Bacteroidetes, respectively (Fig. 2). Within Alphaproteobacteria, the 2 OTUs SAR11-IA and SAR11-IB (Kan et al. 2008) were the most dominant OTUs in both libraries $(44 \pm 3$ and $21 \pm 0.2 \%$ of Alphaproteobacteria clones, respectively, mean $\pm \mathrm{SD}, \mathrm{n}=2$ ). Gammaproteobacteria were dominated by the 3 OTUs Alteromonas macleodii, JTB148 and SAR861 in the C-library, each accounting for $20 \%$ of Gammaproteobacteria clones. By contrast, in the D-library, only the OTU A. macleodii had an important relative contribution (23\% of Gammaproteobacteria clones). In the Dmesocosm, the number of total clones of $A$. macleodii (10) was 2-fold higher than in the C-mesocosm (5). It was further interesting to note that the OTU Thiothrix was detected only in the D-library, where it represented $11 \%$ of Gammaproteobacteria clones. Within the Bacteroidetes, the OTU NS4-1 was specific to the D-library (14\% of Bacteroidetes clones) and the OTU NS5-1 had the highest relative contribution to Bacteroidetes clones in this library (28\% of Bacteroidetes clones). In contrast, in the C-library the 4 OTUs NS5-2, Aegean179, NS7 and Winogradskyella contributed equally to Bacteroidetes (each accounting for roughly $10 \%$ of Bacteroidetes clone sequences). We observed no differences in the contribution of the 3 OTUs determined within the Actinobacteria between the 2 clone libraries.

A $\int$-LIBSHUFF analysis (Schloss et al. 2004) allowed comparison of the 2 clone libraries. When the homologous coverage curve of one library (X) was compared with the heterologous curve $\mathrm{XY}$, neither the comparison $\left(\mathrm{C}_{\mathrm{X}}-\mathrm{C}_{\mathrm{XY}}\right)^{2}$ nor the reverse comparison $\left(\mathrm{C}_{\mathrm{Y}}-\mathrm{C}_{\mathrm{YX}}\right)^{2}$ showed a significant difference between the 2 libraries, with values of $\mathrm{p}=0.0631$ and $\mathrm{p}=0.1928$ for $\left(\mathrm{C}_{\mathrm{X}}-\mathrm{C}_{\mathrm{XY}}\right)^{2}$ and $\left(\mathrm{C}_{\mathrm{Y}}-\mathrm{C}_{\mathrm{YX}}\right)^{2}$, respectively.

\section{Identification of specific CE-SSCP peaks}

To identify the CE-SSCP peaks that were different between the $\mathrm{C}$ - and the D- mesocosms at $t_{8}$ we performed CE-SSCP analysis of several clones from each OTU identified, and 

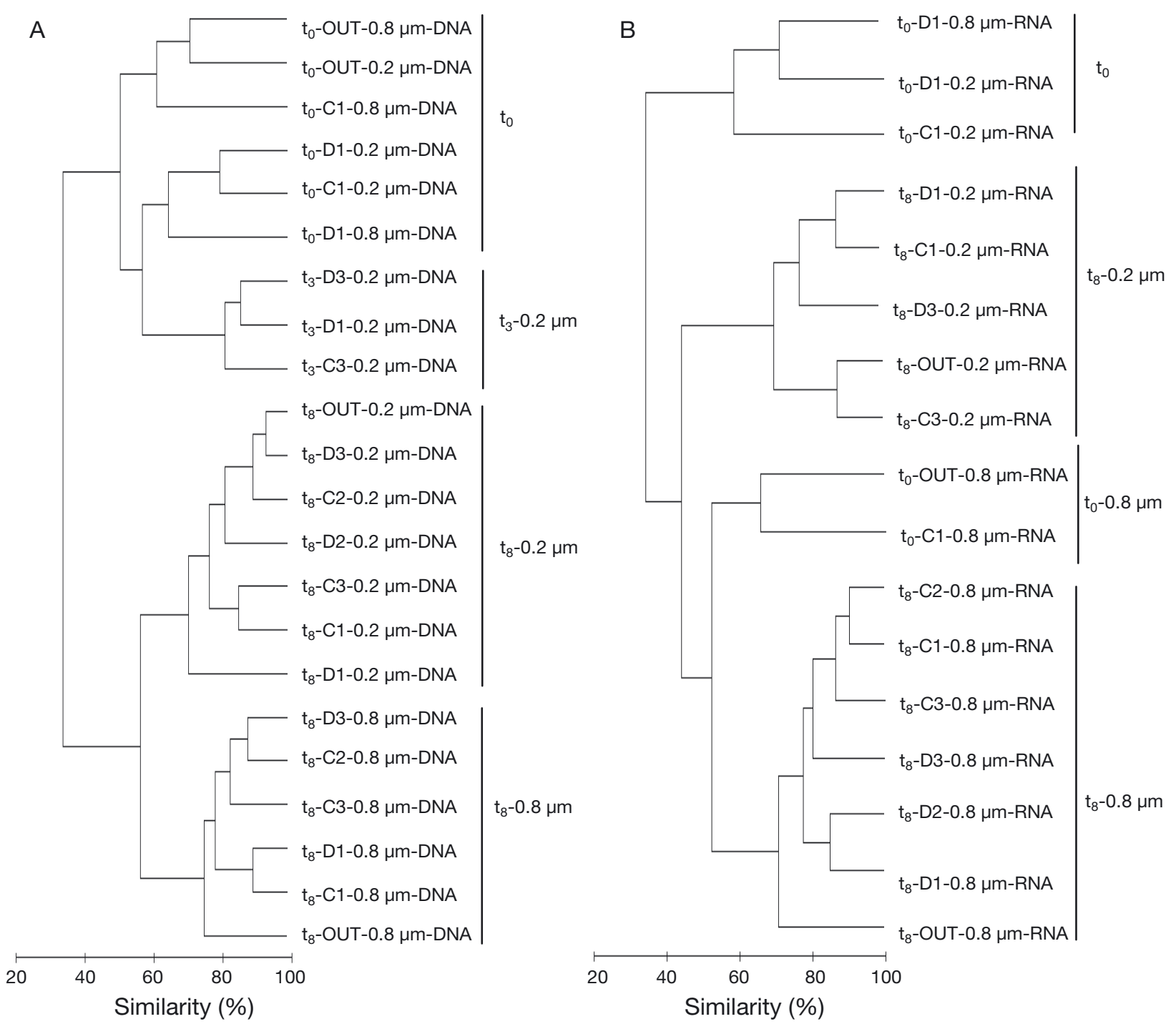

Fig. 1. Similarity dendrograms of the CE-SSCP profiles of (A) the 16S rRNA gene and (B) the 16 rRNA transcripts of the bacterial communities based on the Bray-Curtis distances. The dendrogram was constructed by the complete linkage method. $t_{0}$, $t_{3}$, and $\mathrm{t}_{8}$ refer to sample collection before dust addition, and $3 \mathrm{~d}$ and $8 \mathrm{~d}$ after dust addition, respectively. D1, D2, D3: dust-amended mesocosms; C1, C2, C3: control mesocosms; OUT: samples collected outside the mesocosms; $0.2 \mu \mathrm{m}$ : $<0.8 \mu \mathrm{m}$ size fraction; $0.8 \mu \mathrm{m}: 0.8-3 \mu \mathrm{m}$ size fraction; DNA: CE-SSCP profiles based on 16S rRNA gene; RNA: CE-SSCP profiles based on 16S rRNA transcript

aligned the migration of the clones to the environmental community profile (Fig. 2). One peak that revealed noticeable differences between the C- and the D-mesocosms was identified as Alteromonas macleodii at the end of the experiment (Fig. 2A,B). For the 16S rRNA transcript-based profile of the $>0.8 \mu \mathrm{m}$ size fraction, the relative contribution of this peak to total peak area was about 2-fold higher in the D-mesocosms than that in the C-mesocosms (14 \pm 8 and $7 \pm 1 \%$ of the total peak area, respectively, $\mathrm{n}=3$ ). For the $16 \mathrm{~S}$ rRNA gene based profile, the relative contribution of this peak to total peak area was $11 \pm 2$ and $16 \pm 6 \%(n=3)$ for the $C$ - and D-mesocosms, respectively. For the $<0.8 \mu \mathrm{m}$ size fraction, the relative contribution of this peak to total peak area was, respectively, $2 \pm 1$ and $4 \pm 2 \%$ for the C- and D-mesocosms for the 16S rRNA gene-based profile, and, respectively, $9 \pm 1$ and $6 \pm 6 \%$ for the C- and D-mesocosms for the 16S rRNA transcript-based profile. Other peaks identified were SAR86, SAR11 and Synechococcus, but no differences were detectable for these OTUs.

\section{Contribution of bacterial groups to total abundance}

We used previously designed and 2 specificallydesigned probes for the OTUs Thiothrix and NS5-1 (See 'Materials and methods') to quantify the relative abundance of the major and some more specific bacte- 


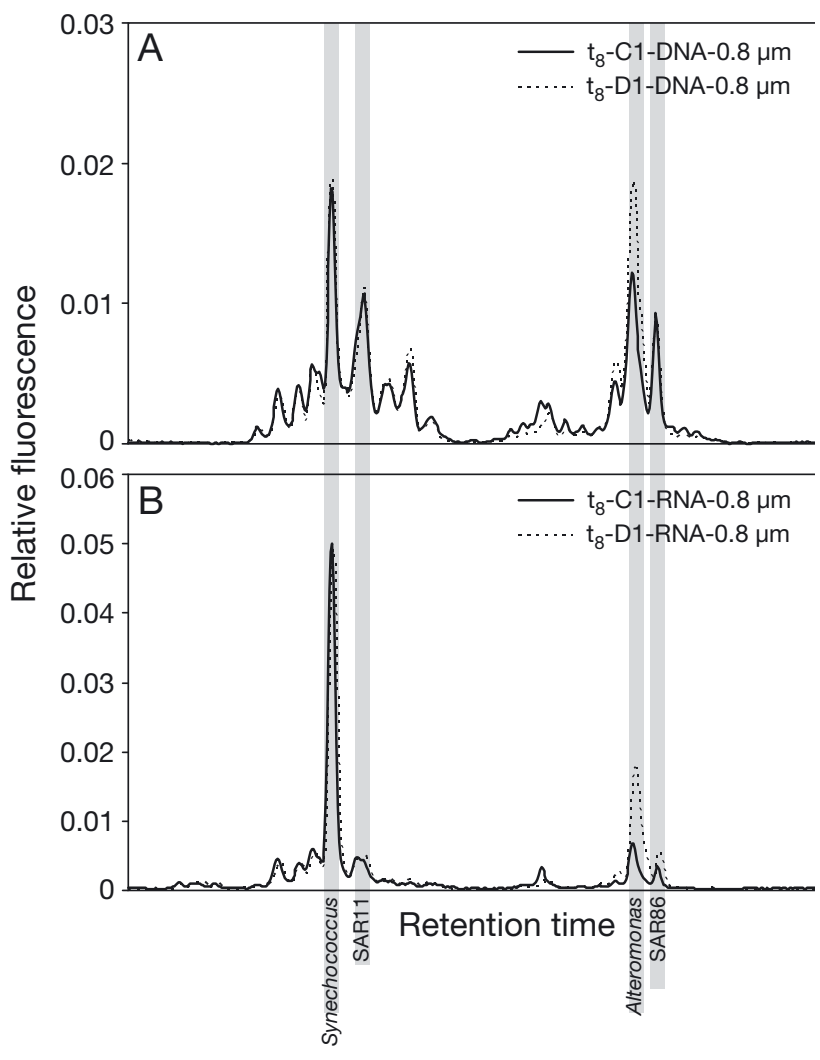

Fig. 2. (A) 16S rRNA gene and (B) 16S rRNA transcript CESSCP profiles showing different peak patterns for the $0.8-3$ $\mu \mathrm{m}$ size fraction in 1 representative control mesocosm $(\mathrm{C} 1$, solid line) superimposed on 1 dust-amended mesocosm (D1, broken line). The shaded stripes show the positions of peaks that were assigned by the clones (named below). SAR86 is a tentatively assigned peak

Table 3. Relative contribution of bacterial groups to bulk bacterial abundance before $\left(\mathrm{t}_{0}\right)$ and $8 \mathrm{~d}$ after dust deposition $\left(\mathrm{t}_{8}\right)$ in control $(\mathrm{C})$ and dust-amended (D) mesocosms, and in samples collected outside the mesocosms (OUT). Means \pm SD of replicate mesocosms are given, except for the OUT sample ( $t_{8}$ OUT) where mean values $\pm \mathrm{SE}$ of 10 microscopic fields are given. For $t_{0}$, results from the $3 \mathrm{C}$ - and D-mesocosms, and the OUT sample are pooled

\begin{tabular}{|c|c|c|c|c|}
\hline & \multicolumn{4}{|c|}{$\begin{array}{l}\text { Relative contribution of bacterial groups } \\
\text { (\% DAPI-cells) }\end{array}$} \\
\hline & $\begin{array}{c}t_{0} \\
(n=7)\end{array}$ & $\begin{array}{c}\mathrm{t}_{8} \\
\mathrm{C}(\mathrm{n}=3)\end{array}$ & $\begin{array}{c}\mathrm{t}_{8} \\
\mathrm{D}(\mathrm{n}=3)\end{array}$ & $\begin{array}{c}\mathrm{t}_{8} \\
\text { OUT }(\mathrm{n}=1)\end{array}$ \\
\hline Bacteria & $67 \pm 15$ & $71 \pm 10$ & $62 \pm 10$ & $60 \pm 3$ \\
\hline Alphaproteobacteria & $36 \pm 10$ & $32 \pm 13$ & $42 \pm 1$ & $31 \pm 3$ \\
\hline SAR11 & $31 \pm 6$ & $42 \pm 7$ & $37 \pm 7$ & $34 \pm 2$ \\
\hline Roseobacter & $8 \pm 3$ & $9 \pm 1$ & $6 \pm 1$ & $9 \pm 2$ \\
\hline Betaproteobacteria & $12 \pm 4$ & $14 \pm 1$ & $7 \pm 1$ & $10 \pm 1$ \\
\hline Gammaproteobacteria & $23 \pm 5$ & $21 \pm 4$ & $20 \pm 6$ & $23 \pm 2$ \\
\hline SAR86 & $8 \pm 2^{\mathrm{a}}$ & $7 \pm 2$ & $8 \pm 3$ & $8 \pm 1$ \\
\hline Alteromonas & $2 \pm 0.8^{\mathrm{a}}$ & $3 \pm 1$ & $5 \pm 2$ & $3 \pm 2$ \\
\hline Thiothrix & $1 \pm 0.3^{\mathrm{a}}$ & $2 \pm 1$ & $1 \pm 0.1$ & $2 \pm 1$ \\
\hline Bacteroidetes & $34 \pm 9$ & $17 \pm 4$ & $34 \pm 9$ & $27 \pm 3$ \\
\hline NorSea72 & $4 \pm 1^{\mathrm{a}}$ & $5 \pm 0.3$ & $5 \pm 2$ & $5 \pm 1$ \\
\hline NS5-1 & $0.7 \pm 0.6^{\mathrm{a}}$ & $0.7 \pm 0.1$ & $2 \pm 0.2$ & $2 \pm 0.4$ \\
\hline${ }^{\mathrm{a}} \mathrm{n}=3$ & & & & \\
\hline
\end{tabular}

rial groups determined by the clone libraries. Overall, no differences in the abundance of the major bacterial groups were detectable between treatments, and we observed some minor differences only at the OTU level. For the description of the relative abundance of most of the bacterial groups determined in the present study, we have therefore pooled the results from the different treatments and time points $(\mathrm{n}=14)$. The proportion of cells that hybridized with the general EUB probes and the NON338 probe was on average $65 \pm$ $13 \%(\mathrm{n}=14)$ and $3 \pm 2 \%(\mathrm{n}=14)$ respectively. SAR11 had important contributions to bulk abundance in the C- and D-mesocosms and in the OUT samples throughout the experiment $(35 \pm 7 \%$ of DAPI-stained cells respectively, $\mathrm{n}=14$, results from all treatments and time points pooled), while the contribution of Roseobacter remained low ( $8 \pm 3 \%$ of DAPI-stained cells, $\mathrm{n}=14$ ) (Table 3 ). The relative contributions of Gammaproteobacteria, SAR86 and Thiothrix were independent of treatment and did not vary over time $(22 \pm 4,8 \pm 2,1 \pm 1 \%$ of DAPI-stained cells, respectively, $\mathrm{n}=14$ ). Even though relative abundances were overall low (2 to $5 \%$ of DAPI-stained cells), Alteromonas revealed slightly higher abundances in the Dthan in the C-mesocosms $8 \mathrm{~d}$ after dust addition (5 and $3 \%$ of DAPI-stained cells, respectively, $\mathrm{n}=3$ in both cases). Bacteroidetes displayed similar relative abundances in the D-mesocosms and the OUT samples throughout the experiment $(31 \pm 6 \%$ of DAPI-stained cells, $\mathrm{n}=11$, data from all D-mesocosms and OUT samples pooled), but the relative abundance of Bacteroidetes was substantially lower in the C-mesocosms at $\mathrm{t}_{8}(17 \pm 4 \%$ of DAPI-stained cells, $\mathrm{n}=3)$ (Table 3). While the OTU NorSea72 did not display any differences between treatments ( $5 \pm 1 \%$ of DAPIstained cells, $\mathrm{n}=14$ ), the OTU NS5-1 was slightly more abundant in the Dthan in the $\mathrm{C}$-mesocosms at $\mathrm{t}_{8}(2 \pm$ $0.2 \%$ and $0.7 \pm 0.1 \%$ of DAPI-stained cells, respectively, $\mathrm{n}=3$ in both cases). Combining the results of all bacterial groups considered here, no significant differences between the $\mathrm{C}$ - and the Dmesocosms were detectable after $8 \mathrm{~d}$ (Kruskal-Wallis, p > 0.8).

\section{DISCUSSION}

The impact of dust deposition on the biogeochemistry of a LNLC marine ecosystem and in particular on bacterial community structure has not, to the best of our knowledge, so far been investi- 
gated using trace-metal-clean in situ mesocosms. The 2 previous studies that addressed this question were carried out in microcosm experiments (up to 15 l) (Reche et al. 2009, Lekunberri et al. 2010). The lack of in situ observations is due to the episodic nature of atmospheric dust deposition that makes it difficult to follow related in situ changes at appropriate temporal and spatial scales. For the biogeochemical parameters determined during the DUNE project and the bacterial community structure, the control mesocosms represented the temporal changes that occurred in the Bay of Elbo well (Guieu et al. 2010), and the 3 replicate mesocosms exhibited high reproducibility in this study. Large in situ mesocosms represent therefore an original and appropriate tool to investigate an atmospheric dust event in a LNLC environment in close to in situ conditions.

During the DUNE project, dust deposition resulted in a rapid, but transient, increase in dissolved inorganic phosphate concentrations by $12 \mathrm{nM}$ at the surface (Pulido-Villena et al. 2010). From our observations, dust deposition resulted in an approximately 2-fold increase in the concentration of chl $a$ in the upper $5 \mathrm{~m}$ over the duration of the experiment(Table 1). In contrast, bacterial heterotrophic abundance did not reveal any marked increase at $5 \mathrm{~m}$ depth following dust addition (Table 1). The P-fertilizing effect of dust on the autotrophic community confirms previous microcosm experiments in the Mediterranean Sea (Bonnet et al. 2005, Herut et al. 2005, Lekunberri et al. 2010) and it has also been demonstrated for heterotrophic bacterial metabolism (Herut et al. 2005, Pulido-Villena et al. 2008, Reche et al. 2009, Lekunberri et al. 2010). Only in one study was this bulk response accompanied by noticeable changes in the bacterial community structure (Lekunberri et al. 2010). In this study, the addition of dust or inorganic phosphorus (P) to coastal Mediterranean waters resulted in a similar bacterial community structure in both treatments. This observation led to the conclusion that $\mathrm{P}$ introduced by dust addition was the factor driving observed changes in bacterial community structure (Lekunberri et al. 2010). Changes in bacterial community structure following $\mathrm{P}$ addition to Mediterranean waters are also reported from previous experimental studies (Lebaron et al. 2001, Schäfer et al. 2001, Pinhassi et al. 2006). In these previous studies, the final $\mathrm{P}$ concentrations were, however, substantially higher $(0.3$ to $0.6 \mu \mathrm{M})$ than in the DUNE mesocosms amended with dust $(\leq 17 \mathrm{nM})$ (Pulido-Villena et al. 2010). If, in the present study, the input of the low $P$ concentration due to dust addition had a structuring effect on the bacterial community composition, it was probably hidden in the natural temporal trend (Fig. 1).

Over the $8 \mathrm{~d}$ of the experiment, we observed a pronounced temporal evolution of the total (16S rRNA genes) and active (16S rRNA transcripts) bacterial community structure (Fig. 1). Changes in bacterial community structure are frequently observed on a seasonal time scale (Ghiglione et al. 2005, Fuhrman et al. 2006, Mary et al. 2006, Lami et al. 2009), but they can also occur on shorter temporal scales (Hewson et al. 2006, Lamy et al. 2009). Changes in bacterial community structure on a weekly time scale could be of importance during different phases of phytoplankton blooms, phases of transition between seasons or following environmental perturbations (Fandino et al. 2001, West et al. 2008). Roughly $2 \mathrm{wk}$ prior to the DUNE experiment, a Saharan dust event (K. Desboeuf \& F. Dulac pers. comm.) and heavy rainfalls (Wagener et al. 2010) occurred at the study site, which could explain the temporal pattern in bacterial community structure we observed during our study.

Despite this natural temporal trend, dust deposition had an impact, detectable at the OTU level, on a few particular features of the bacterial community composition. The OTUs Thiothrix and Alteromonas macleodii, belonging to Gammaproteobacteria, and the Bacteroidetes OTU NS5-1 were more abundant in or specific to the dust-amended mesocosms, compared to the control mesocosms at the end of the experiment (Table 2; Fig.2). The presence of these OTUs has so far not been linked to dust deposition. The OTU Thiothrix has been observed in clone libraries of the North Pacific coast (Brown et al. 2005) and it was present in many samples taken during the Global Ocean Sampling (Shaw et al. 2008). The cluster NS5 appears to be common in the coastal environment of temperate (DeLong et al. 1993, Alonso et al. 2007) and high latitude regions (Bano \& Hollibaugh 2002). A noticeable pattern observed in our study was the relatively high contribution of the species $A$. macleodii to the active bacterial community of the $>0.8 \mu \mathrm{m}$ fraction in the Dmesocosms (Fig. 2). A. macleodii and related species are among the most widespread cultured Gammaproteobacteria. Previous observations that A. macleodii rapidly responds in nutrient enrichment experiments (Pukall et al. 1999, Schäfer et al. 2000) and that its presence in situ is often found in association with particulate matter (Acinas et al. 1999, López-López et al. 2005) have led to the idea that $A$. macleodii has an opportunistic way of life, which favours its dominance in response to enhanced nutrient supply. The analysis of the complete genome of a surface ecotype of $A$. macleodii indicates that it is well adapted to rapidly changing environmental conditions, by means of complex patterns of regulation and environmental sensing, features that could be linked to transient particle attachment (Ivars-Martinez et al. 2008).

Beside the clear impact on $\mathrm{P}$ cycling mentioned above, it is also expected that dust addition alters iron cycling. During the DUNE experiment, dissolved iron 
concentrations (Guieu et al. 2010, Wagener et al. 2010) decreased rapidly following dust addition, mainly due to scavenging by rapidly sinking large dust particles. This was confirmed by measurements of particulate iron and aluminium, and the analysis of the sediment traps deployed below each of the mesocosms that revealed that a fraction of dust particles rapidly sunk after their deposition at the surface (Guieu et al. 2010, Wagener et al. 2010). Based on Stokes's law, we estimated that dust particles with a diameter $<3.2 \mu \mathrm{m}$ remained in the upper $5 \mathrm{~m}$ layer of the D-mesocosms until the end of the experiment. These small particles represented $20 \%$ of the total volume of dust introduced into the mesocosms at the beginning of the experiment, and they could provide a new, but not directly available, source of iron to microorganisms. Grazing of these particles by protists could be one means of liberating colloidal- or particle-bound iron as dissolved iron (Barbeau et al. 1996). The reduced availability of dissolved iron and the presence of small iron-rich particles could also act jointly to stimulate the production of siderophores by heterotrophic bacteria (Granger \& Price 1999, Kraemer 2004). We hypothesize that small Saharan dust particles could have provided a favourable environment for iron acquisition by heterotrophic bacteria and could explain the increased activity of some bacteria like Alteromonas macleodii in the D-mesocosms. Results from experiments conducted in parallel to this study demonstrate that the iron solubility capacity of seawater in the D-mesocoms increased by the end of the experiment (Wagener et al. 2010) and lend support to our hypothesis that dust addition stimulates the production of siderophores by heterotrophic bacteria.

Acknowledgements. The work presented here is part of the doctoral dissertation of M.L. supported by a grant of the French Ministère de l'Education Nationale de l'Enseignement Supérieur et de la Recherche. The DUNE project was funded by the ANR under the contract 'ANR-07-BLAN-0126-01'. We thank the 'Réserve naturelle de Scandola Parc Naturel Régional de Corse' in particular J.M. Dominici and collaborators for professionalism and cooperation in the implementation of the field work in the Bay of Elbo. We thank M. Deschatres for her help in sample collection and filtration. The involvement of F. Louis, J. M. Grisoni, D. Luquet, C. Ridame, E. Pulido-Villena, C. Brunet, L. Gilleta and C. Rouvières during the DUNE-1 experiment is greatly acknowledged. We are grateful to N. West for her help in probe design and C. Manes for her advice on recovery of DNA and RNA from environmental samples. We thank 2 anonymous reviewers who helped to improve the manuscript.

\section{LITERATURE CITED}

Acinas SG, Anton J, Rodriguez-Valera F (1999) Diversity of free-living and attached bacteria in offshore Western Mediterranean waters as depicted by analysis of genes encoding 16S rRNA. Appl Environ Microbiol 65:514-522
Alonso C, Warnecke F, Amann R, Pernthaler J (2007) High local and global diversity of Flavobacteria in marine plankton. Environ Microbiol 9:1253-1266

Amann RI, Krumholz L, Stahl DA (1990) Fluorescent-oligonucleotide probing of whole cells for determinative, phylogenetic, and environmental studies in microbiology. J Bacteriol 172:762-770

- Amann R, Glockner F, Neef A (1997) Modern methods in subsurface microbiology: in situ identification of microorganisms with nucleic acid probes. FEMS Microbiol Rev 20:191-200

Bano N, Hollibaugh J (2002) Phylogenetic composition of bacterioplankton assemblages from the Arctic Ocean. Appl Environ Microbiol 68:505-518

Barbeau K, Moffett J, Caron D, Croot P, Erdner D (1996) Role of protozoan grazing in relieving iron limitation of phytoplankton. Nature 380:61-64

Bonnet S, Guieu C (2006) Atmospheric forcing on the annual iron cycle in the western Mediterranean Sea: a 1-year survey. J Geophys Res 111, C09010, doi:10.1029/ 2005JC003213

> Bonnet S, Guieu C, Chiaverini J, Ras J, Stock A (2005) Effect of atmospheric nutrients on the autotrophic communities in a low nutrient, low chlorophyll system. Limnol Oceanogr 50:1810-1819

Boyd PW, Jickells T, Law CS, Blain S and others (2007) Mesoscale iron enrichment experiments 1993-2005: synthesis and future directions. Science 315:612-617

Brown MV, Schwalbach MS, Hewson I, Fuhrman JA (2005) Coupling 16S-ITS rDNA clone libraries and automated ribosomal intergenic spacer analysis to show marine microbial diversity: development and application to a time series. Environ Microbiol 7:1466-1479

Cassar N, Bender M, Barnett B, Fan S, Moxim W, Levy H, Tilbrook B (2007) The Southern Ocean biological response to aeolian iron deposition. Science 317:1067-1070

Clarke K, Warwick R (2001) Changes in marine communities: an approach to statistical analysis and interpretation, 2nd ed. Primer-E, Plymouth

> Daims H, Brühl A, Amann R, Schleifer KH, Wagner M (1999) The domain-specific probe EUB 338 is insufficient for the detection of all bacteria: development and evaluation of a more comprehensive probe set. Syst Appl Microbiol 22: $434-444$

> Delbes C, Moletta R, Godon JJ (2000) Monitoring of activity dynamics of an anaerobic digester bacterial community using 16S rRNA polymerase chain reaction-single-strand conformation polymorphism analysis. Environ Microbiol 2:506-515

> DeLong E, Franks D, Alldredge A (1993) Phylogenetic diversity of aggregate-attached vs. free-living marine bacterial assemblages. Limnol Oceanogr 38:924-934

Duarte C, Dachs J, Llabrés M, Alonso-Laita P and others (2006) Aerosol inputs enhance new production in the subtropical northeast Atlantic. J Geophys Res 111, G04006, doi:10.1029/2005JG000140

- Eilers H, Pernthaler J, Glockner FO, Amann R (2000) Culturability and in situ abundance of pelagic bacteria from the North Sea. Appl Environ Microbiol 66:3044-3051

- Eilers H, Pernthaler J, Peplies J, Glockner FO, Gerdts G, Amann R (2001) Isolation of novel pelagic bacteria from the German Bight and their seasonal contributions to surface picoplankton. Appl Environ Microbiol 67: 5134-5142

Ewing B, Hillier L, Wendl M, Green P (1998) Base-calling of automated sequencer traces using phred. I. Accuracy assessment. Genome Res 8:175-185 
Fandino L, Riemann L, Steward G, Long R, Azam F (2001) Variations in bacterial community structure during a dinoflagellate bloom analyzed by DGGE and 16S rDNA sequencing. Aquat Microb Ecol 23:119-130

Fuhrman JA, Hewson I, Schwalbach MS, Steele JA, Brown MV, Naeem S (2006) Annually reoccurring bacterial communities are predictable from ocean conditions. Proc Natl Acad Sci USA 103:13104-13109

Ghiglione JF, Larcher M, Lebaron P (2005) Spatial and temporal scales of variation in bacterioplankton community structure in the NW Mediterranean Sea. Aquat Microb Ecol 40:229-240

Glöckner FO, Fuchs BM, Amann R (1999) Bacterioplankton compositions of lakes and oceans: a first comparison based on fluorescence in situ hybridization. Appl Environ Microbiol 65:3721-3726

Granger J, Price N (1999) The importance of siderophores in iron nutrition of heterotrophic marine bacteria. Limnol Oceanogr 44:541-555

Guieu C, Dulac F, Desboeufs K, Wagener T and others (2010) Large clean mesocosms and simulated dust deposition: a new methodology to investigate responses of marine oligotrophic ecosystems to atmospheric inputs. Biogeosciences 7:2765-2784

> Herut B, Zohary T, Krom M, Mantoura R and others (2005) Response of East Mediterranean surface water to Saharan dust: on-board microcosm experiment and field observations. Deep-Sea Res II 52:3024-3040

> Hewson I, Steele JA, Capone DG, Fuhrman JA (2006) Temporal and spatial scales of variation in bacterioplankton assemblages of oligotrophic surface waters. Mar Ecol Prog Ser 311:67-77

Hill PG, Zubkov M, Purdie DA (2010) Differential responses of Prochlorococcus and SAR11-dominated bacterioplankton groups to atmospheric dust inputs in the tropical Northeast Atlantic Ocean. FEMS Microbiol Lett 306:82-89

> Hugenholtzt P, Huber T (2003) Chimeric 16S rDNA sequences of diverse origin are accumulating in the public databases. Int J Syst Evol Microbiol 53:289-293

Ivars-Martinez E, Martin-Cuadrado A, D'Auria G, Mira A and others (2008) Comparative genomics of two ecotypes of the marine planktonic copiotroph Alteromonas macleodii suggests alternative lifestyles associated with different kinds of particulate organic matter. ISME J 2:1194-1212

Jickells TD, An ZS, Andersen KK, Baker AR and others (2005) Global iron connections between desert dust, ocean biogeochemistry, and climate. Science 308:67-71

> Jurado E, Dachs J, Duarte C, Simó R (2008) Atmospheric deposition of organic and black carbon to the global oceans. Atmos Environ 42:7931-7939

Kan J, Evans SE, Chen F, Suzuki MT (2008) Novel estuarine bacterioplankton in rRNA operon libraries from the Chesapeake Bay. Aquat Microb Ecol 51:55-66

Klepac-Ceraj V, Ceraj I, Polz MF (2006) Clusterer: extendable java application for sequence grouping and cluster analyses. Online J Bioinformatics 7:15-21

> Kraemer S (2004) Iron oxide dissolution and solubility in the presence of siderophores. Aquat Sci 66:3-18

> Laghdass M, West NJ, Batailler N, Caparros J and others (2010) Impact of lower salinity waters on bacterial heterotrophic production and community structure in the offshore NW Mediterranean Sea. Environ Microbiol Rep 2:761-769

Lami R, Ghiglione JF, Desdevises Y, West NJ, Lebaron P (2009) Annual patterns of presence and activity of marine bacteria monitored by 16S rDNA-16S rRNA fingerprints in the coastal NW Mediterranean Sea. Aquat Microb Ecol 54:199-210
Lamy D, Obernosterer I, Laghdass M, Artigas LF and others (2009) Temporal changes of major bacterial groups and bacterial heterotrophic activity during a Phaeocystis globosa bloom in the eastern English Channel. Aquat Microb Ecol 58: 95-107

- Lebaron P, Parthuisot N, Catala P (1998) Comparison of blue nucleic acid dyes for flow cytometric enumeration of bacteria in aquatic systems. Appl Environ Microbiol 64: $1725-1730$

Lebaron P, Servais P, Troussellier M, Courties C and others (2001) Microbial community dynamics in Mediterranean nutrient-enriched seawater mesocosms: changes in abundances, activity and composition. FEMS Microbiol Ecol 34:255-266

> Lee DH, Zo YG, Kim SJ (1996) Nonradioactive method to study genetic profiles of natural bacterial communities by PCR-single-strand-conformation polymorphism. Appl Environ Microbiol 62:3112-3120

Lekunberri I, Lefort T, Romero E, Vazquez-Dominguez E and others (2010) Effects of a dust deposition event on coastal marine microbial abundance and activity, bacterial community structure and ecosystem function. J Plankton Res 32:381-396

> López-López A, Bartual S, Stal L, Onyshchenko O, RodríguezValera F (2005) Genetic analysis of housekeeping genes reveals a deep-sea ecotype of Alteromonas macleodii in the Mediterranean Sea. Environ Microbiol 7:649-659

Ludwig W, Strunk O, Westram R, Richter L, Meier H (2004) ARB: a software environment for sequence data. Nucleic Acids Res 32:1363-1371

Maidak BL, Cole JR, Lilburn TG, Parker CT Jr and others (2001) The RDP-II (ribosomal database project). Nucleic Acids Res 29:173-174

Manz W, Amann R, Ludwig W, Wagner M, Schleifer KH (1992) Phylogenetic oligodeoxynucleotide probes for the major subclasses of proteobacteria: problems and solutions. Syst Appl Microbiol 15:593-600

Manz W, Amann R, Ludwig W, Vancanneyt M, Schleifer K (1996) Application of a suite of 16S rRNA-specific oligonucleotide probes designed to investigate bacteria of the phylum Cytophaga-Flavobacter-Bacteroides in the natural environment. Microbiol 142:1097-1106

Marie D, Partensky F, Simon N, Guillou L, Vaulot D (2000) Flow cytometry analysis of marine picoplankton. In: De Maggio S (ed) Living color: protocols in flow cytometry and cell sorting. Springer Verlag, Berlin, p 421-454

Maring H, Savoie D, Izaguirre M, Custals L, Reid J (2003) Mineral dust aerosol size distribution change during atmospheric transport. J Geophys Res 108, 8592, doi: 8510.1029/2002JD002536

Mary I, Cummings DG, Biegala IC, Burkill PH, Archer SD, Zubkov MV (2006) Seasonal dynamics of bacterioplankton community structure at a coastal station in the western English Channel. Aquat Microb Ecol 42:119-126

Mills MM, Ridame C, Davey M, La Roche J, Geider RJ (2004) Iron and phosphorus co-limit nitrogen fixation in the eastern tropical North Atlantic. Nature 429:292-294

Morris RM, Rappé MS, Connon SA, Vergin KL, Siebold WA, Carlson CA, Giovannoni SJ (2002) SAR 11 clade dominates ocean surface bacterioplankton communities. Nature 420:806-810

> Pernthaler A, Pernthaler J, Amann R (2002) Fluorescence in situ hybridization and catalyzed reporter deposition for the identification of marine bacteria. Appl Environ Microbiol 68:3094-3101

> Pinhassi J, Gómez-Consarnau L, Alonso-Sáez L, Sala MM, Vidal M, Pedrós-Alió C, Gasol JM (2006) Seasonal 
changes in bacterioplankton nutrient limitation and their effects on bacterial community composition in the NW Mediterranean Sea. Aquat Microb Ecol 44:241-252

Pukall R, Päuker O, Buntefuß D, Ulrichs G and others (1999) High sequence diversity of Alteromonas macleodii-related cloned and cellular 16S rDNAs from a Mediterranean seawater mesocosm experiment. FEMS Microbiol Ecol 28: 335-344

Pulido-Villena E, Wagener T, Guieu C (2008) Bacterial response to dust pulses in the western Mediterranean: implications for carbon cycling in the oligotrophic ocean. Global Biogeochem Cycles 22, GB1020, doi:10.1029/ 2007GB003091

Pulido-Villena E, Rérolle V, Guieu C (2010) Transient fertilizing effect of dust in P-deficient LNLC surface ocean. Geophys Res Lett 37, L01603, doi:10.1029/2009GL041415

Reche I, Ortega-Retuerta E, Romera O, Pulido-Villena E, Morales-Baquero R, Casamayor E (2009) Effect of Saharan dust inputs on bacterial activity and community composition in Mediterranean lakes and reservoirs. Limnol Oceanogr 54:869-879

Ridame C, Guieu C (2002) Saharan input of phosphate to the oligotrophic water of the open western Mediterranean Sea. Limnol Oceanogr 47:856-869

Schäfer H, Servais P, Muyzer G (2000) Successional changes in the genetic diversity of a marine bacterial assemblage during confinement. Arch Microbiol 173:138-145

Schäfer H, Bernard L, Courties C, Lebaron P and others (2001) Microbial community dynamics in Mediterranean

Editorial responsibility: Hugh Ducklow, Woods Hole, Massachusetts, USA nutrient-enriched seawater mesocosms: changes in the genetic diversity of bacterial populations. FEMS Microbiol Ecol 34:243-253

Schloss PD, Larget BR, Handelsman J (2004) Integration of microbial ecology and statistics: a test to compare gene libraries. Appl Environ Microbiol 70:5485-5492

Seitzinger S, Sanders R (1999) Atmospheric inputs of dissolved organic nitrogen stimulate estuarine bacteria and phytoplankton. Limnol Oceanogr 44:721-730

Sekar R, Pernthaler A, Pernthaler J, Warnecke F, Posch T, Amann R (2003) An improved protocol for quantification of freshwater Actinobacteria by fluorescence in situ hybridization. Appl Environ Microbiol 69:2928-2935

> Shaw AK, Halpern AL, Beeson K, Tran B, Venter JC, Martiny JBH (2008) It's all relative: ranking the diversity of aquatic bacterial communities. Environ Microbiol 10: 2200-2210

Wagener T, Guieu C, Leblond N (2010) Effects of dust deposition on iron cycle in the surface Mediterranean Sea: results from a mesocosm seeding experiment. Biogeosciences Discuss 7:2799-2830

West NJ, Obernosterer I, Zemb O, Lebaron P (2008) Major differences of bacterial diversity and activity inside and outside of a natural iron-fertilized phytoplankton bloom in the Southern Ocean. Environ Microbiol 10:738-756

Zemb O, Haegeman B, Delgenes J, Lebaron P, Godon J (2007) Safum: statistical analysis of SSCP fingerprints using PCA projections, dendrograms and diversity estimators. Mol Ecol Notes 7:767-770

Submitted: April 21, 2010; Accepted: October 4, 2010 Proofs received from author(s): December 20, 2010 